\title{
Ruminal protein metabolites and fibre fermentation differ among nonfibre carbohydrate and protein sources*
}

\author{
M.B. Hall ${ }^{1}$ and C.C. Larson ${ }^{2}$ \\ ${ }^{1}$ USDA-ARS U.S. Dairy Forage Research Center \\ 1925 Linden Drive West, Madison, WI 53706 USA \\ ${ }^{2}$ Department of Animal Sciences, University of Florida \\ P.O. Box 110910, Gainesville, FL 32611 USA
}

\begin{abstract}
Effects of nonfibre carbohydrate source (NFC) and protein degradability (RDP) in vivo on concentrations of $\mathrm{NH}_{3}$, amino acids, and branch chain volatile fatty acids (BCVFA) in ruminal fluid, and on in situ disappearance of neutral detergent fibre (NDF) were evaluated. Treatment differences noted in BCVFA and amino acid concentrations suggest that ruminal protein digestion or use differs by NFC source. NFC source and the interaction of NFC $\times$ RDP affected in situ NDF disappearance; the effects did not appear to purely $\mathrm{pH}$ related. In situ NDF disappearance provided relative, not absolute, evaluation of NDF digestibility.
\end{abstract}

KEY WORDS: nonfibre carbohydrates, starch, sucrose, pectin, fibre, protein

\section{INTRODUCTION}

Nonfibre carbohydrates (NFC) encompass the dietary carbohydrates exclusive of the cellulose and hemicellulose found in neutral detergent fibre (NDF). They include mono- and oligosaccharides, starch, fructans and non-starch, non-NDF polysaccharides. The NFC can provide 5 to more than $40 \%$ of diet dry matter, depending upon forage composition and amount of supplementation with byproduct feeds or grains. In most current nutrient supply estimates for dairy cattle, all NFC are estimated to be equal in their potential yield of metabolizable nutrients to the animal (NRC, 2001), except as this is affected by rate of

\footnotetext{
* Supported by a Grant from the dairy farmer-sponsored Milk Check-Off program

Special thanks to G. A. Broderick for his assistance with amino acid and ammonia analyses

${ }^{1}$ Corresponding author: e-mail: hall@animal.ufl.edu
} 
fermentation (CPM Dairy, 1998). Although there is evidence that various NFC differ in their effects on animal performance and ruminal measures beyond what is readily explained by fermentation rate (Heldt et al., 1999; Sannes et al., 2002), their effects on nutrient supply to the animal, and their interaction with protein sources have not been well explored. The objective of this study was to evaluate the effects of altering the dietary complement of NFC at two different dietary concentrations of ruminally degradable protein (RDP) on ruminal measures of microbial fermentation products and NDF disappearance.

\section{MATERIAL AND METHODS}

Six ruminally cannulated, multiparous lactating Holstein cows were randomly assigned to a series of dietary treatments in a partially balanced, incomplete Latin square design with three 21 day periods (14 days for acclimation and 7 days for sample collection). In the $3 \times 2$ factorial arrangement of treatments, the three NFC dietary treatments were starch (ST), soluble fibre plus sugar (SF), or sugar (SU), achieved by altering the proportions of ground maize, citrus pulp, liquid molasses, and sucrose included in the diets. Inclusion of $48 \%$ soyabean meal alone (+RDP) or a combination of expeller soyabean meal (SoyPLUS; West Central Soy, Ralston, IA) and $48 \%$ soyabean meal (-RDP) were used to modify dietary protein degradability. On a dry matter basis, all diets were formulated to contain similar basal concentrations of roughage (maize silage at 250 to $260 \mathrm{~g} \mathrm{~kg}^{-1}$, sorghum silage at $120 \mathrm{~g} \mathrm{~kg}^{-1}$, and cottonseed hulls at $40 \mathrm{~g} \mathrm{~kg}^{-1}$ ), to be isonitrogenous, and to contain similar concentrations of total NFC and NDF (Table 1). Dry matter intake was measured daily.

Table 1. Chemical composition of study diets

\begin{tabular}{lcccccc}
\hline Measured component & \multicolumn{5}{c}{ Diets $^{1}$} \\
\cline { 2 - 7 } $\mathrm{g} \mathrm{kg}^{-1}$ of dry matter & ST+RDP & ST-RDP & SF+RDP & SF-RDP & SU+RDP & SU-RDP \\
\hline CP & 171 & 156 & 166 & 159 & 173 & 163 \\
NDF & 387 & 381 & 411 & 405 & 372 & 391 \\
Sugar & 40 & 44 & 79 & 72 & 131 & 136 \\
Starch & 231 & 237 & 135 & 150 & 141 & 117 \\
NDSF $^{2}$ & 20 & 31 & 52 & 47 & 42 & 51 \\
NDFCP & 36 & 39 & 38 & 38 & 45 & 40 \\
\hline
\end{tabular}

${ }^{1}$ dietary treatments: ST - starch, SF - sugar + soluble fibre, SU - sugar, +RDP - higher ruminal protein degradability, -RDP - lower ruminal protein degradability

${ }^{2}$ neutral detergent-soluble fibre

Extent of in situ ruminal NDF disappearance of dried sorghum silage was measured on days 16,17 , and 18 of each period by the dacron bag technique using polyester bags $(10 \times 20 \mathrm{~cm})$ with an average pore size of $53 \pm 10 \mu \mathrm{m}$ (Bar Diamond, Inc., Parma, ID, USA) and $5 \mathrm{~g}$ of air dry ground sorghum silage per bag (Nocek, 1988). Duplicate 
bags inserted into nylon mesh bags were incubated in the rumen for $0,6,12,18,24$, 30 , and $48 \mathrm{~h}$. The weights of NDF residue in each bag were determined using heatstable, alpha-amylase and were corrected for ash content.

Ruminal fluid samples ( $\sim 500 \mathrm{~mL})$ were collected via ruminal cannulae on day 20 of each period, starting prior to feeding and continuing hourly for the next $12 \mathrm{~h}$. $\mathrm{pH}$ was measured immediately. Ruminal fluid samples were analysed for organic acids, ruminal ammonia, and amino acids (expressed as leucine equivalents).

Dry matter intake and NDF disappearance at each hour were analysed with the MIXED procedure of SAS (1996) with cow as a random variable. All other ruminal measures, including $\mathrm{pH}$ (analysed as the hydrogen ion concentration), were analysed as repeated measures. The orthogonal contrasts ST vs SU+SF, and $\mathrm{SU}$ vs SF were performed. Significance was declared at $\mathrm{P} \leq 0.05$.

This experiment was carried out under protocols approved by the University of Florida Institutional Animal Care and Use Committee. Due to multiple health disorders not related to the study, one of the cannulated cows was removed from the study and was not sampled in the third period.

\section{RESULTS AND DISCUSSION}

Not unexpectedly, ruminal $\mathrm{NH}_{3}$ was greater on the $+\mathrm{RDP}$ diets but this effect was only noted as an RDP by time interaction in hours 1 through 3 (Table 2); there was no effect of NFC treatment. In the same time frame, ruminal free amino acids differed by NFC, with ST less than SU + SF; the interactions of NFC or RDP by

Table 2. Least squares means of ruminal measures for all diets ${ }^{1}$

\begin{tabular}{lcccccc}
\hline Measure $^{2}$ & ST+RDP & ST-RDP & SF+RDP & SF-RDP & SU+RDP & SU-RDP \\
\hline DMI, kg & 26.2 & 20.9 & 21.0 & 23.0 & 21.9 & 23.8 \\
$\mathrm{NH}_{3}, \mathrm{mM}$ & 12.3 & 10.8 & 12.1 & 9.6 & 11.8 & 10.1 \\
$\mathrm{AA}, \mathrm{mM}$ & 1.64 & 1.46 & 1.86 & 1.73 & 1.94 & 1.76 \\
BCVFA, mM & 3.79 & 3.48 & 3.31 & 2.87 & 2.45 & 2.26 \\
$\mathrm{NH}_{3} / \mathrm{BCVFA}$ & & & & & & \\
$\quad$ at h 2 & 3.41 & 3.08 & 3.33 & 2.71 & 5.77 & 3.73 \\
at h 3 & 2.92 & 2.69 & 2.92 & 2.49 & 4.48 & 3.29 \\
pH & 5.99 & 5.98 & 6.11 & 6.03 & 5.83 & 6.07 \\
24 h IS & 0.19 & 0.26 & 0.21 & 0.20 & 0.16 & 0.21 \\
30 h IS & 0.26 & 0.32 & 0.32 & 0.26 & 0.22 & 0.27 \\
48 h IS & 0.39 & 0.42 & 0.43 & 0.40 & 0.39 & 0.39 \\
\hline
\end{tabular}

${ }^{1}$ values represent $\mathrm{NH}_{3}$ for sampling hours 1 through 3; and AA, BCVFA, and $\mathrm{pH}$ sampling hours 0 through 12. Dietary treatments: ST - starch, SF - sugar + soluble fibre, SU - sugar, +RDP - higher ruminal protein degradability, -RDP - lower ruminal protein degradability

${ }^{2} \mathrm{DMI}$ - dry matter intake, AA - amino acids (leucine equivalents), BCVFA - branched chain volatile fatty acids, IS - in situ NDF disappearance as a proportion of original NDF 
time was significant for all hours. The BCVFA differed by NFC source with ST greater than $\mathrm{SU}+\mathrm{SF}$, and $\mathrm{SF}$ tending to be greater than $\mathrm{SU}(\mathrm{P}=0.07)$. The $\mathrm{BCVFA}$ tended to differ by $\mathrm{RDP}$ by time $(\mathrm{P}=0.10)$. The ratio of $\mathrm{NH}_{3}$ to BCVFA differed among NFC treatments, though both are protein breakdown products. Evaluation of these ratios at two and three $\mathrm{h}$ after feeding showed a tendency for effects of both NFC and RDP $(\mathrm{P}<0.10)$. The ratio for SU was greater than that of SF. Sannes et al. (2002) reported decreased ruminal BCVFA in dairy cattle with substitution of sucrose for maize meal.

Ruminal $\mathrm{pH}$ showed a highly significant NFC by time interaction, but no other effect of dietary treatment. The ruminal $\mathrm{pH}$ of cows consuming the SU+RDP diet was lower over time than that noted on other diets. This is consistent with the report that cows consuming a diet containing rapidly fermenting carbohydrates and relatively more ruminally degradable protein had lower ruminal $\mathrm{pH}$ than animals consuming a diet with less ruminally degradable protein (Aldrich et al., 1993).

In situ disappearance of NDF differed for NFC and NFC $\times$ RDP in h 6, 18, 24, and 30 , and tended to differ for NFC $\times \mathrm{RDP}$ at $48 \mathrm{~h}(\mathrm{P}=0.05)$. Differences did not appear to be due solely to ruminal $\mathrm{pH}$.

The interaction of NFC and RDP tended to affect intake $(\mathrm{P}=0.08)$.

\section{CONCLUSIONS}

Differences in ruminal amino acid and BCVFA concentrations, and in the ratio of ammonia to BCVFA suggest that ruminal protein digestion or use differs by NFC source. The differences in in situ disappearance of NDF indicate that fibre digestion can be affected by dietary NFC source and the interaction of NFC and protein source. Accordingly, in situ results are not likely to be uniform across diets and may be best suited for relative, not absolute, evaluation of NDF digestibility.

\section{REFERENCES}

Aldrich J.M., Muller L.D., Varga G.A., Griel L.C., 1993. Nonstructural carbohydrate and protein effects on rumen fermentation, nutrient flow, and performance of dairy cows. J. Dairy Sci. 76, 1091-1105

CPM Dairy, Version 1.0, 1998. Dairy Nutrition Modeling Program. University of Pennsylvania, Cornell University, W. H. Miner Institute, Kennet Square, PA, Ithaca, NY, and Chazy, NY

Heldt J.S., Cochran R.C., Stokka G.L., Farmer C.G., Mathis C.P., Titgemeyer E.C., Nagaraja T.G., 1999. Effects of different supplemental sugars and starch fed in combination with degradable intake protein on low-quality forage use by beef steers. J. Anim. Sci. 77, 2793-2802

National Research Council, 2001. Nutrient Requirements of Dairy Cattle. $7^{\text {th }}$ revised Edition. National Academy Press, Washington, DC

Nocek J.E., 1988. In situ and other methods to estimate ruminal protein and energy digestibility: Review. J. Dairy Sci. 71, 2051-2069

Sannes R.A., Messman M.A., Vagnoni D.B., 2002. Form of rumen-degradable carbohydrate and nitrogen on microbial protein synthesis and protein efficiency of dairy cows. J. Dairy. Sci. 85, 900-908

SAS, 1996. The SAS system for Windows, Release 6.12. SAS Institute, Inc., Cary, NC 